\title{
Benefits Management as a Path for Project Management Offices Contribute to Programs and Influence on Project Performance
}

\author{
Vaniele Guimaraes Carvalho ${ }^{1}$, Sanderson César Macêdo Barbalho ${ }^{2}$, Gladston Luiz da Silva ${ }^{3}$, José Carlos de Toledo ${ }^{4}$ \\ ${ }^{1}$ Postgraduate Program in Mechatronics Systems, Faculty of Technology, University of Brasilia - UnB, Brazil \\ ${ }^{2}$ Department of Production Engineering, Faculty of Technology, University of Brasilia - UnB, Brazil \\ ${ }^{3}$ Department of Statistics, Institute of Exact Sciences, University of Brasília - UnB, Brazil \\ ${ }^{4}$ Department of Production Engineering, Federal University of São Carlos - UFSCar, Brazil \\ Correspondence: Vaniele Guimaraes Carvalho, Postgraduate Program in Mechatronics Systems, Faculty of Technology, \\ University of Brasilia - UnB, Brazil.
}

Received: November 14, 2017

doi:10.11114/bms.v4i1.2976
Accepted: January 30, $2018 \quad$ Online Published: February 2, 2018

URL: https://doi.org/10.11114/bms.v4i1.2976

\begin{abstract}
This paper analyses the relationships between the Project Management Offices (PMOs) functions and the results of performance indicators of product development projects, considering the triple constraint: time, cost, quality. A survey was conducted on a sample of 35 Brazilian manufacturing companies, which have a Product Development Process and a support of PMO for product projects. Although the survey's results pointed out the presence of Project Management Offices on companies' structure, it does not guarantee the success on project's triple constraints, the benefits management was a PMO function correlated to cost performance. It suggests that if a company structure projects as programs, an effort to guarantee the focus on benefits rather than only on project's results can drive good performance on costs.
\end{abstract}

Keywords: project management offices, new product development, project performance, triple constraint, PMO functions, benefits management

\section{Introduction}

Project Management Office (PMO) is a structure that provides important support to project managers, especially in the provision of management methodologies and multi-project administration. Some studies (Dai \& Wells, 2004; Julian, 2008) have shown that the awareness of performance on cost, time and quality of projects managed in organizations that have PMOs, have been better than in organizations without these structures. Futhermore, other researches have shown that PMOs are not static structures or with a fixed set of functions independent of the organization where they work. Instead, PMOs are strongly determined by the company's business and by the project performance objectives (Aubry, Hobbs, Müller \& Blomquist, 2010).

Aiming to advance the understanding of how Project Management Offices are structured in companies that develop new products and their implications for project performance, one survey was conducted on a non-probabilistic sample of 35 companies, which have an active new products development (NPD) process and which have PMOs to provide support for them. The purpose of the survey was gathering data of the relation between PMO functions and performance of triple constraint in NPD projects.

Triple constraint is a concept stated in the PMBOK® Guide (Project Management Institute [PMI], 2013) that suggests the use of the Earned Value Analysis (EVA) method as a way to control project progress. This method was developed by NASA in order to monitor its contracts and to incorporate indicators that encompass synergistic management of scope, time, and cost (Garel, 2013). By using that, the project succeeds in delivering the contracted scope, on schedule and costs planned.

In spite of core aspect of projects on project management literature, an increasing complexity in the environment of organizations is emerging (Jugend, Barbalho \& Silva, 2015) in which not only projects are presents, but also programs and portfolios (PMI, 2013). In this context, there are discussions in the literature about PMO impacts on project performance, such as Spelta and Albertin (2012), Unger, Germünden and Aubry (2012) and Spalek (2013). Besides, 
Jugend et al. (2015) discusses PMO's influence portfolio indicators. These studies did not directly address the relationship between PMO functions and performance, nor did they focus on projects of companies that develop new products as adressed here.

The paper focuses on the roles played by the PMOs surveyed bringing light to program management theory (The Cabinet Office [TCO], 2011) and its relation with the indicator of project costs, time and scope, the so-called triple constraint or iron triangle of project performance. In this purpose, this paper complements the findings of Barbalho, Silva and Toledo (2017), which diagnoses the benefits management as a function related to cost performance. An open issue is what concerns other program management functions and performance of triple constraint. In addition, how can a PMO contribute to program management objectives? As well, how this finding can contribute to PMO and project performance theory.

Next section shows the main theoretical frameworks used. Later, it is discussed the research methodology and after it is presented the collected data, following by the discussion, addressesing the main reflections about the data presented. It ends with theoretical and practical research considerations and perspectives to its further development.

\section{Project Management Offices in New Product Development}

Ulrich and Eppinger (2008) argue that new product development process is operated throughout different projects. In addition, the life cycle of a product involves a large set of projects cycles: project to make specifications for the product, to design it technically, to certify it in regulatory agencies, to release it, to remove it from the market etc. Each of these project cycles is different from the other and needs to be planned in an unique mode, according to PMBOK® Guide (PMI, 2013).

Clark and Fujimoto (1991) is the pioneer in this study and is still today the main reference in the analysis of new product development (NPD) performance. The 80s automotive industry was analyzed and this book was the first major study of product development focusing on performance indicators. According to the authors, the performance of the product development has been seen as a reflection of long-term capabilities of the company, establishing the total quality of the product, the development lead-time and the productivity as the NPD key performance criteria. The authors also state the PMOs as a liaison organization about different company areas.

There are studies that tried to identify critical success factors for NPD that would affect some product success metrics. Some studies about new product performance focus on factors related to leadership, strategy, organization and planning practices (Cooper \& Kleinschmidt, 1995; Griffin \& Page, 1996; Kahn, Barczak \& Moss 2006; Paladino, 2007) while others focused on activities that generate higher performance (Roberts \& Belotti, 2002; Toledo, Da Silva, Alliprandini \& Ferrari, 2008; Jugend \& Silva, 2010; Mendes \& Toledo, 2012).

Success is a theme that should be better understood, since there is the product success, defined by the following aspects: financial performance, customer value, company's sales percentage of products launched in recent years, time to investment return, market share and product quality (Cooper \& Kleinschmidt, 1995; Griffin \& Page 1996; Kahn et al. 2006; Chiesa \& Frattini, 2007). However, there is also the project success addressing the stakeholders' perception of the success, the impact for the customer and for the team and the company's preparation for the future (Marioka \& Carvalho, 2014; Jordão, Pelegrini, Jordão \& Jeunon, 2015). In some cases, there is also the success of the management of development projects, especially concerning the indicators of cost, scope and project quality, particularly comparing what was planned and what was executed (Marioka \& Carvalho, 2014; Jordão et al., 2015;. Patah \& Carvalho, 2016).

Toledo, Da Silva, De Paula and Jugend (2007), Toledo et al. (2008), Jugend and Silva (2010), and Mendes and Toledo (2012) conducted surveys with several companies from different areas: auto parts, industrial automation and medical device, in order to identify the performance drivers in NPD for Brazilian Companies. The results indicate the importance of the requirements planning and the management skills of project managers as key elements involved in successful projects. The above authors found there are success factors related to the technical performance of products that can make them superior to competing products, which confirm previous international research in the area (Cooper \& Kleindshmith, 1995; Griffin \& Page, 1996). They also found a new driver represented by the documentation of technical details of products. As an example, the medical device companies rely on a good interpretation of customer needs and creativity in engineering solutions. The authors also identified that approval activities are relate to the product's success in the studied companies.

Project Management Office (PMO) is an organizational structure to facilitate project management activities and to achieve improvements in organization's management process through portfolio management and project alignment with corporate strategy (Crawford, 2002).

Dai and Wells (2004) compared project management (PM) practices in companies with and without PMO. They identified that tPM practices are more effective on companies with PMO, especially about lessons learned registration 
and about PM application of methodologies and techniques.

Hobbs and Aubry (2007) conducted an extensive analytical study on the PMOs activities. The presence and degree of importance of 27 different functions and roles of the PMOs were analyzed. These functions and roles were grouped based on factor analysis, generating the following groups: (a) Monitoring and controlling activities of project performance; (b) Development of skills and project management methodologies; (c) Multi-project management; (d) Strategic management; and (e) Organizational learning. The authors identified other important activities involving execution of specialized tasks for the project managers as well as recruitment, selection, evaluation and determining their salaries. These functions were not grouped because of conceptual consistency.

PMI (2013) proposed another widely used PMO typology classification. It stratifies PMO as supporters, with role of consulting to projects and with low degree of control over them; controllers, which provide support, but demand the adherence to standard methodology of the projects and have a moderate degree of control; and diretives, which controls the projects by managing them directly.

For Hobbs and Aubry (2007), activities of monitoring and controlling projects performance are the most important within the PMO. Their results were used to compose the list of functions submitted for respondents in the survey used for the analysis presented in this paper.

Recent studies identified a positive relation between PMO functions and project performance. Spelta and Albertin (2012) addressed previous researches that argue PMOs main contributions are related to time, cost and quality results of projects. Their research identified portfolio control as the main driver of PMO adoption. Unger et al. (2012) found PMOs' controlling functions as explanation of the quality of project portfolio management. Spalek (2013) states in a research with 259 PMOs a difficulty in demonstrating the added value of them. However, it is argued that when the companies successfully operate its PMO, they positively influence industrial engineering performance especially in long-term planning, multi-project environment, and according the maturity of the company's PMO.

Some studies of Brazilian researchers focus on new products development projects under a prism of project management practices. Jucá Jr., Conforto and Amaral (2010) studied software developer companies under the focus of CMMI (Capability Maturity Model Integration) and concluded that this standard is not appropriate to analyze NPD practices in small businesses. Da Silva, Mello, Siqueira, Godoy and Salgado (2010) discuss the risk management techniques application in auto parts companies. Conforto, Salum, Amaral, Da Silva and Almeida (2014) discuss practices of agile project management in innovative projects.

Toledo et al. (2007) surveyed a number of small Brazilian high technology firms trying to understand the drivers for new product success. The results comply with international researches while identifying the importance of a strong and detailed up-front homework and management skills associated with team-based design as drivers. However, the authors identified that the activity of "providing project documentation" is a driver too. Da Silva, Toledo, Mendes and Jugend (2007) present a complementary work in which technology firms from medical and industrial automation are compared. Automation companies have success projects strongly related to superior technical performance against competitors; medical companies rely on interpretation of consumer needs and generation of product ideas. Moreover, the authors identified that homologation activities correlates to product success, which is a novelty in this kind of study.

Few analyzed studies have addressed PMO linked to new product development projects. Barbalho, Amaral, Kernbichler, Richter and Torres (2009) discuss PMO structuration to facilitate the execution of large projects in small companies. Rabechini Jr, Carvalho, Rodrigues and Sbragia (2011) analyze the NPD of an auto parts company, in which PM practices potentiated by PMO were motivated by the need to reduce the lack of projects' technical memory. Barbalho, Toledo, Rojic and Sillos (2014) address the different functions that PMO can take on NPD projects with very specific activities for this kind of project. Barbalho and Toledo (2014) analyze the transitions in a PMO of a technology-based company, featuring the changes in functions performed by the PMO. Jugend et al. (2015) argue that PMO can provide to NPD portfolio management.

A previous report of the study here addressed shows the benefits management as the function more strongly related to project performance, and mainly to project cost compliance (Barbalho, Carvalho, Silva \& Toledo, 2016; Barbalho et al. 2017). The present paper explores this result according to the program management theory and tries understanding better the data about functions and performance indicators.

According to PMI (2013), a program is a group of related projects, subprograms and activities managed in a coordinated way to obtain benefits that would not be available if they would handled individually. Complementing the previous explanation, TCO (2011) states that a program is a temporary and flexible organization, created to coordinate, drive and supervise the implementation of a group of related projects, aiming to deliver results and benefits aligned to the organizational strategic objectives. 
TCO (2011) explains the logic behind the concepts of benefits: the outputs of the projects build a new capability that will enable the outcomes (results), as long as a new operational state is achieved after the transition of the new capabilities to the operational environment. The results must bring the planned benefits, and those contribute to one or more corporate objectives. Consequently, the concept of program is close to the necessary alignment between PMO activities and company strategy (Hobbs \& Aubry, 2007).

Rijke, Herk, Zevenbergen, Ashley, Hertogh and Heuvelhof (2014) justify that the separation between projects and programs must occur because the relationship of the program to its projects is different from the relationship of the project to its deliveries and work packages. Pellegrinelli (2011) states that, organized within a program, projects can become islands of order, with relative stability and predictability and focused on the delivery of their objectives, although distinct, but well defined and directed by an integrating management.

Thiry (2010) states that there exist four main intrinsic elements to programs that are enough for maintaining their sustainability, maturity and excellence: the management of decisions, the management of benefits, the management of stakeholders and the program governance. Between these four main elements, the author opines that the management of benefits is the most important.

Breese, Jenner, Serra and Thorp (2015) argue there is evidence that a focus on benefits management improves the success rate of projects and programs, thus helping to achieve organizational goals. Then, it is important to point out that the combination of all projects required within a program generates benefits, and when managed in a coordinated way delivers value to the organizations.

The main differences between projects and programs are related to narrow versus large scopes and focus on benefit planning, detailed project planning versus high-level plans to guide detailed planning, management of project teams versus leadership and management of project managers, and monitoring/controlling project work versus monitoring program components progress (PMI, 2013). These elements can explain the results of data gathered as will be discussed later.

\section{Method}

The research methodology adopted for this study was an exploratory and quantitative survey with descriptive analysis in order to take conclusions throught the survey diagnostic related to the main functions performed by PMOs and its impact on companies that develop new products. According Garcia (1995) a descriptive analysis of the data must be performed, aiming to understand the variables and to build hypotheses for the use of more sophisticated statistical techniques. In this study, the references of Bussab and Morettin (2003), and Heiberger and Holland (2004) were considered to plan data gathering and analysis.

The survey was initially focused on companies that develop new products in the state of São Paulo, in Brazil, but it has been extended to other states of the country through a snowball approach in networks of new product development experts and Brazilian chapters of project management institute. The first version of the questionnaire was personally applied, in three companies, by the researcher, aiming the validation of their structure and questions. After this initial step, the questionnaire was refined and consolidated and then it was released on Internet, being applied to a set of 35 companies that develop new products in different industrial sectors such as automotive, automation, equipment and capital goods and consumer goods.

The surveyed companies come from different industries and this research does not bear a potential to demonstrate a multi-industry reality since it was not mandatory to identify the entrepreneurial area of each company, considering that it is not the purpose to relate functions or performance to types of business. According to the tasks performed by PMOs, respondents should indicate in Likert scale, from one to five, the degree of PMO effort on the company for each statement. There were 31 functions of the PMO analyzed in this study, which can be separated into three groups: Support to the Higher Hierarchical Levels; Support to Project Managers and their teams; and Projects, Programs and Portfolios Management. This classification aimed to compose the functions described by Hobbs and Aubry (2007), Pellegrinelli and Garagna (2009) and Barbalho et al. (2014) to the PMBOK® Guide rating due to the greater familiarity that the project management community (survey respondents) has with the classification and terminology used by the Guide. Each function had a label to facilitate the analysis by respondents.

In the first group, there were eight functions identified as Support to the Higher Hierarchical Levels. This functions are: (X1) - Report the project status to senior management, (X2) - Provide coaching to senior management, (X3) Participate in strategic planning, (X4) - Benefits management, (X5) - Recruitment, selection, evaluation and remuneration determination for PMs, (X6) - Networking and environmental monitoring, (X7) - Participation in multi-department's committees, and (X8) - Promote the project management within the company.

In the second group, there were twelve functions identified as Support to Project Managers and their teams. These 
functions are: (X9) - Develop and implement a standardized methodology; (X10) - Develop Project Management skills, including training; (X11) - Implement and operate the information system on projects; (X12) - Monitor and control the PMO performance; (X13) - Provide tools without any specific effort to standardize it; (X14) - Implement and manage the lessons learned database; (X15) - Implement and manage the risk database; (X16) - Provide coaching to project managers; (X17) - Management of engineering changes; (X18) - Perform specialized activities for project managers (preparation of schedules, etc); (X19) - Management of manufacturing items for prototypes/deliveries; and (X20) Management of purchasing items for prototypes/deliveries.

In the third group, eleven functions were identified as Projects, Programs and Portfolios Management. These functions are: (X21) - Provide proactive ways for organizational learning between projects; (X22) - Monitor and control the project performance; (X23) - Coordination between projects; (X24) - Develop and maintain a scoreboard of projects; (X25) - Manage one or more portfolios; (X26) - Identify, select and prioritize new projects; (X27) - Manage files of project documentation; (X28) - Manage one or more programs; (X29) - Conduct project audits; (X30) - Set resources allocation among projects; and (X31) - Conduct evaluation of project to its end.

In the questionnaire, the respondents also made statements about their perception of the projects performance considering the indicators to analyse the triple constraint. The statements do not directly relate the PMO functions to performance, thus, it was possible to make a more assertive and isolated analysis of the problems of projects performance in the respondents' companies. The indicators to analyze the triple constraint were: (X32) - Perception of the performance in time; (X33) - Perception of the performance in cost; and (X34) - Perception of the performance of volume changes in specifications.

For every activity the likert scale was in very high effort (answer "5") or high (answer "4") by the PMO, as those ones less relevant on office operations - very low effort (answer "1") or low (answer "2"). The level of effort "3" indicates an intermediate response. The perception of the project performance was also answered using the five levels, being that the five (answer "5") is related to higher agreement over better results on that metric and one (answer " 1 ") is related to lower concordance. These answers were correlated to conclude on which functions of PMO can help companies to improve their project success metrics.

These answers lead to make statistical analysis and calculate the correlation between PMO functions and NPD's project performance in cost, time and scope as well as analyzing its significance. Data were downloaded into an MS Excel datasheet, properly treated and uploaded into SAS $\odot$ software. A Spearman correlation and multiple tests were used, and their results are presented and discussed below.

\section{Results}

The data gathered allowed to calculate the relative frequencies according to the PMO effort to perform functions for supporting higher hierarchical levels, supporting project managers and their teams, and directing projects and/or programs and/or portfolios; and the respondents perception of the level that projects match time, cost or scope performance.

The correlation analysis was performed between the PMO functions and the perception of the project performance.

Initially, only the variables of functions were analyzed. The results revealed that, in support to higher hierarchical levels, the function of PMO: "Benefits management" (X4), has low effort in the companies surveyed, as most responses were "very low" (1) and "low" (2). Summarizing PMOs efforts analysis with the 31 listed functions the highlights of higher efforts are related to provide methodology to project managers and their teams and reporting to senior management. As it was highlighted for PMOs lower efforts are management of benefits and setting the remuneration for project managers, and the function related to business environment monitoring, all related to the group of senior management support. These results are reported on Barbalho et al. (2016).

The performance of projects in perception of the triple constraint for the respondents is represented in Figure 1. 


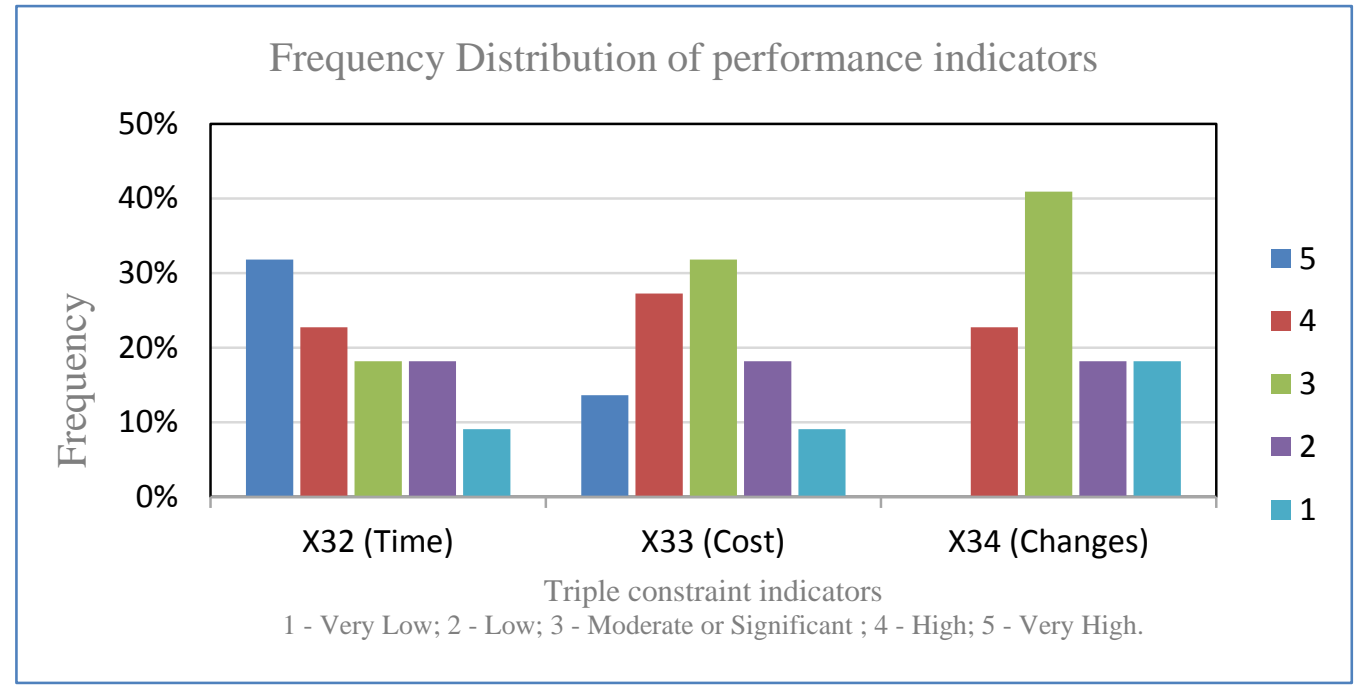

Figure 1. Perception of the projects performance in the triple constraint

The performance indicator more affected by PMO is the perception in Time (X32), then, the perception in Costs (X33) and at lastly the perception of changes in specifications (X34), which had none answer stated as " 5 ". This suggests the projects analyzed have the best results in conformity with planned times.

The results of perception of the projects performance in the triple constraint were associated to the answers for PMO functions. Due to the ordinal nature of the variables associated with the function and the perception of project performance, the association levels have been analyzed based on the Spearman correlation coefficient (rs). Regarding the indicators, represented by the variables X32, X33 and X34, there are significant correlation levels, according to Table 1.

Table 1. Spearman correlation levels for PMO functions correlated to performance of triple constraints

\begin{tabular}{|c|c|c|c|c|}
\hline Indicators & Functions & Variables & rs & P-value \\
\hline \multirow{3}{*}{$\begin{array}{l}\text { X32 - Time } \\
\text { performance }\end{array}$} & $\begin{array}{l}\text { Support to higher } \\
\text { hierarchical levels }\end{array}$ & $\begin{array}{c}\mathrm{X} 1 \text { - Report the project status to senior } \\
\text { management }\end{array}$ & 0.389 & 0.022 \\
\hline & \multirow{2}{*}{$\begin{array}{l}\text { Management of projects, } \\
\text { programs and portfolios }\end{array}$} & $\begin{array}{c}\text { X27 - Manage files of project } \\
\text { documentation }\end{array}$ & 0.351 & 0.0390 \\
\hline & & X28 - Manage one or more Programs & 0.384 & 0.0230 \\
\hline \multirow{3}{*}{$\begin{array}{l}\text { X33 - Cost } \\
\text { performance }\end{array}$} & $\begin{array}{l}\text { Support to higher } \\
\text { hierarchical levels }\end{array}$ & X4 - Benefits management & 0.435 & 0.0090 \\
\hline & \multirow{2}{*}{$\begin{array}{l}\text { Support to project managers } \\
\text { and their teams }\end{array}$} & $\begin{array}{l}\text { X14 - Implement and manage the lessons } \\
\text { learned database }\end{array}$ & 0.350 & 0.0400 \\
\hline & & $\begin{array}{c}\text { X15 - Implement and manage the risk } \\
\text { database }\end{array}$ & 0.367 & 0.0300 \\
\hline $\begin{array}{l}\text { X34 - Changes } \\
\text { in specification }\end{array}$ & No sign & ant correlation with the analyzed functions & & \\
\hline
\end{tabular}

The most relevant correlation observed was between performance on costs and benefits management (X4), an interesting positive and moderate correlation indicating relations between PMO functions and cost performance. To verify if the results would remain unchanged, once a set of inferences had been reported simultaneously, the correction for multiple tests was performed by applying the Hommel, Hochberg, and FDR tests.

Hommels (1988) method is based on Simes'test (Simes, 1986), where p-value for a joint test of any set of K hypotheses with $\mathrm{p}$-values $\mathrm{p}(1) \leq \mathrm{p}(2) \leq \ldots \leq \mathrm{p}(\mathrm{K})$ is $\min \{(\mathrm{K} / 1) \mathrm{p}(1),(\mathrm{K} / 2) \mathrm{p}(2), \ldots,(\mathrm{K} / \mathrm{K}) \mathrm{p}(\mathrm{K})\}$. The Hommel-adjusted $\mathrm{p}$-value for test $\mathrm{j}$ is the maximum of all such Simes $\mathrm{p}$-values, taken over all joint tests that include $\mathrm{j}$ as one of their components.

Hochberg (1988) demonstrates that Holm's step-down adjustments control the family wise error rate even when calculated in step-up fashion. Since the adjusted p-values are uniformly smaller for Hochberg's method than for Holm's method, the Hochberg method is more powerful. However, this improved power comes from the cost of having to make the assumption of independence and uniform distribution under their respective null hypotheses.

FDR method controls the false discovery rate and not the family wise error rate. The method requests adjusted p-values by using the linear step-up method of Benjamini and Hochberg (1995). These p-values do not control the family wise 
error rate, but they control the false discovery rate in some cases.

In applying the aforementioned tests, functions were joined by groups and analyzed on SAS@. Only correlations to X32 and X33 were tested because they have p-values under 0.05 . The results are presented in Table 2.

Table 2. P-Value Adjustment Information for PMO functions and performance of triple constraints correlations.

\begin{tabular}{|c|c|c|c|c|c|c|c|c|c|}
\hline \multirow[b]{2}{*}{ Group } & \multirow[b]{2}{*}{ Indicator } & \multicolumn{4}{|c|}{ X32 } & \multicolumn{4}{|c|}{$\mathbf{X 3 3}$} \\
\hline & & Raw & $\begin{array}{c}\text { Stepdown } \\
\text { Bonferroni }\end{array}$ & Hochberg & FDR & Raw & $\begin{array}{c}\text { Stepdown } \\
\text { Bonferroni }\end{array}$ & Hochberg & FDR \\
\hline \multirow{8}{*}{ I } & $\mathrm{X} 1$ & 0.0220 & 0.1760 & 0.1760 & 0.1760 & 0.2610 & 10.000 & 0.6591 & 0.5964 \\
\hline & $\mathrm{X} 2$ & 0.3957 & 10.000 & 0.9137 & 0.7342 & 0.6526 & 10.000 & 0.6591 & 0.6591 \\
\hline & X3 & 0.9137 & 10.000 & 0.9137 & 0.9137 & 0.5977 & 10.000 & 0.6591 & 0.6591 \\
\hline & $\mathrm{X} 4$ & 0.3735 & 10.000 & 0.9137 & 0.7342 & 0.0090 & 0.0720 & 0.0720 & 0.0720 \\
\hline & $\mathrm{X} 5$ & 0.8564 & 10.000 & 0.9137 & 0.9137 & 0.6591 & 10.000 & 0.6591 & 0.6591 \\
\hline & X6 & 0.4589 & 10.000 & 0.9137 & 0.7342 & 0.1033 & 0.7231 & 0.6591 & 0.4132 \\
\hline & $\mathrm{X} 7$ & 0.0709 & 0.4963 & 0.4963 & 0.2836 & 0.2982 & 10.000 & 0.6591 & 0.5964 \\
\hline & $\mathrm{X} 8$ & 0.5963 & 10.000 & 0.9137 & 0.7951 & 0.4974 & 10.000 & 0.6591 & 0.6591 \\
\hline \multirow{12}{*}{ II } & X9 & 0.6522 & 10.000 & 0.9401 & 0.8696 & 0.0545 & 0.5450 & 0.5450 & 0.2180 \\
\hline & $\mathrm{X} 10$ & 0.2226 & 10.000 & 0.9401 & 0.5342 & 0.6689 & 10.000 & 0.6990 & 0.6990 \\
\hline & $\mathrm{X} 11$ & 0.3190 & 10.000 & 0.9401 & 0.5469 & 0.3156 & 10.000 & 0.6990 & 0.4734 \\
\hline & $\mathrm{X} 12$ & 0.0557 & 0.6684 & 0.6684 & 0.3720 & 0.6557 & 10.000 & 0.6990 & 0.6990 \\
\hline & $\mathrm{X} 13$ & 0.8969 & 10.000 & 0.9401 & 0.9401 & 0.2168 & 10.000 & 0.6990 & 0.4289 \\
\hline & $\mathrm{X} 14$ & 0.1139 & 10.000 & 0.9401 & 0.4556 & 0.0395 & 0.4345 & 0.4345 & 0.2180 \\
\hline & $\mathrm{X} 15$ & 0.3027 & 10.000 & 0.9401 & 0.5469 & 0.0301 & 0.3612 & 0.3612 & 0.2180 \\
\hline & X16 & 0.8951 & 10.000 & 0.9401 & 0.9401 & 0.5017 & 10.000 & 0.6990 & 0.6689 \\
\hline & $\mathrm{X} 17$ & 0.1915 & 10.000 & 0.9401 & 0.5342 & 0.2502 & 10.000 & 0.6990 & 0.4289 \\
\hline & $\mathrm{X} 18$ & 0.0620 & 0.6820 & 0.6820 & 0.3720 & 0.6990 & 10.000 & 0.6990 & 0.6990 \\
\hline & X19 & 0.5321 & 10.000 & 0.9401 & 0.7982 & 0.2262 & 10.000 & 0.6990 & 0.4289 \\
\hline & X20 & 0.9401 & 10.000 & 0.9401 & 0.9401 & 0.0988 & 0.8892 & 0.6990 & 0.2964 \\
\hline \multirow{11}{*}{ III } & $\mathrm{X} 21$ & 0.3869 & 10.000 & 0.6289 & 0.5022 & 0.4835 & 10.000 & 0.8382 & 0.7425 \\
\hline & $\mathrm{X} 22$ & 0.0442 & 0.3978 & 0.3978 & 0.1458 & 0.3335 & 10.000 & 0.8382 & 0.7425 \\
\hline & $\mathrm{X} 23$ & 0.0530 & 0.4240 & 0.4240 & 0.1458 & 0.4259 & 10.000 & 0.8382 & 0.7425 \\
\hline & $\mathrm{X} 24$ & 0.4109 & 10.000 & 0.6289 & 0.5022 & 0.3219 & 10.000 & 0.8382 & 0.7425 \\
\hline & $\mathrm{X} 25$ & 0.0944 & 0.6608 & 0.6289 & 0.2077 & 0.6019 & 10.000 & 0.8382 & 0.7425 \\
\hline & $\mathrm{X} 26$ & 0.3607 & 10.000 & 0.6289 & 0.5022 & 0.6075 & 10.000 & 0.8382 & 0.7425 \\
\hline & $\mathrm{X} 27$ & 0.0386 & 0.3860 & 0.3860 & 0.1458 & 0.5522 & 10.000 & 0.8382 & 0.7425 \\
\hline & $\mathrm{X} 28$ & 0.0227 & 0.2497 & 0.2497 & 0.1458 & 0.7680 & 10.000 & 0.8382 & 0.8382 \\
\hline & $\mathrm{X} 29$ & 0.6289 & 10.000 & 0.6289 & 0.6289 & 0.8382 & 10.000 & 0.8382 & 0.8382 \\
\hline & $\mathrm{X} 30$ & 0.5672 & 10.000 & 0.6289 & 0.6289 & 0.3030 & 10.000 & 0.8382 & 0.7425 \\
\hline & X31 & 0.2621 & 10.000 & 0.6289 & 0.4805 & 0.4727 & 10.000 & 0.8382 & 0.7425 \\
\hline
\end{tabular}

The results of Tables 1 and 2 show that although six functions are correlated with time and cost indicators with p-values below 0.05 and 0.01 (X1, X4, X14, X15, X27 and X28), when Multiple tests are performed only Benefits Management (X4) remains correlated with the cost performance of the projects in the surveyed PMOs. As a whole, Barbalho et al. (2017) discusses these data. In this paper, a study of the functions related to programs management will be addressed.

\section{Discussion}

The data analyzed showed that in the non-probabilistic sample studied only Benefits Management (X4) function, which was described in literature as one of the main functions of program management, has a real significant relationship with some of triple restriction indicators of new product projects.

In product development projects, the programs management can be considered an important function within large companies, since it is common that projects are being carried out in a platform format (Wheelwright \& Clark, 1992), in which several product models are derived from a single development effort. This means that the specific products can be managed as a project, while, in general, the development effort would happen through management of programs. Considering that $23 \%$ of the surveyed sample represent the companies that have over 1000 employees and considering that, in general, the benefits management has not been identified as a crucial function in the PMO. Because of that, a hypothesis can be formulated and analyzed in future researches. This hypothesis is the possibility to exist an important program management factor within large companies and the functions are partly performed by PMOs. 
Furthermore, the fact that there is a correlation between programs management and perception of the improvement in time indicators (see Table 1) confirms the hypothesis mentioned above. Even though this correlation has been weak and has not been proven by the p-value tests used. The point is that in product development projects the biggest driver of costs is the time (Ali, Krapfel Jr. \& LaBahn, 1995). In other words, the longer the development time, the higher the project cost will be. Moreover, the most commonly used resource is labor, thus, the longer it is allocated in the project, the more person-hour value is required to be added at the cost of development. This is possible by addressing aspects related to the focus of the projects so that they do not interfere the development of solutions, which cannot be used for the benefit of all projects in development.

Considering the literature review carried out in this study, the programs management could be analyzed based on the management of decisions, stakeholders, strategic alignment, program governance and benefits management. The research data has shown that report to senior management, which represents a function with impact on deadlines, can contribute to integrated decision making of the project. Since the top management participate in decisions that have greater impact on business, it is one of the main stakeholder in programs and determinant in the governance.

In addition, the research has shown that the programs management function also has an impact on deadlines (see Table 1). As there has been no deployment of the programs management function, using the concept of Hobbs and Aubry (2007) in which program management is understood as an integrated project management, it may be considered the need to better detail the function of the programs in PMOs. This would make easier to identify PMO activities related to the programs and which influences performance. On the other hand, it can be considered that there is an important impact of the functions related to the programs that PMOs execute and the results of the projects deadline.

In general, considering the benefit management and its cost impact as well as the report to senior management and program management with their impact on deadlines, it is noted in the research that program-linked functions are important in PMOs of the NPD project, being correlated with the performance of the projects under the influence of the offices.

\section{Final Considerations}

Of the 31 PMO functions analyzed in this study, 27 were derived from other studies based on literature review focusing on PMOs that support projects of any typology. The other four were added because there were clues in the literature regarding their presence in PMOs that supported product development projects.

Time and cost performance can be improved by PMO functions, but in different ways, according to data presented in Table 1. However, the statistics did not confirm the relations, but partial results presented in this study can be used as hypothesis to be planned and analysed in future researches. Report for senior managers, manage project files and program management have different focuses and can be better detailed for testing the relations described in this study.

For cost, one way to success can be support to project managers and teams by means of managing and disseminating databases for risk and project knowledge, and mainly working on program management, specially regarding to program benefits.

Managers have been focused their attention on provide project management methodology as one of the most present functions of PMOs researched in this sample, and is not correlated to any indicator of triple constraint in this research. On the other hand, Benefits Management is one of the functions of less effort in studied PMOs, in spite of being correlated to cost performance.

From a strategic point of view, it is interesting to observe that the performance of the PMOs related to the programs management, especially to the aspect of the benefits, were more significant than the portfolio aspects. It was considered the sample researched as being product developers companies, although portfolio management is ubiquitous theme than program issues in NPD literature. It is not common to find product development texts that suggest the program aggregating approach, although platform-type projects are common, a typical program mindset. This is a question to be explored more deeply in product development projects, given the results identified in the screen survey.

In this study, PMO functions related to managing benefits can improve cost performance. This result indicates a relation that has not been previously detected by literature. The literature addresses Project Management functions itself or Portfolio Management function and their impacts on indicators or on the perception of indicators improvement. There are evidences that Portfolio Management functions contributes to project portfolio quality (Unger et al. 2012), but there is no evidence linking Program Management activities to perceived performance improvement, which was found in this research. Other Program Management functions such as the management of decisions, the management of stakeholders and the program governance, and their impacts, can be tested in future research as a way to better understand the role of PMOs in Program Management and their results in indicators of projects performance.

Considering the practical implication of this study, it is important to highlight the potential of establishing program 
management functions as PMO activities. Program management functions are, on one side, in the intermediate position between projects, whose functions are strongly provided by project managers, with certifications or not, but focused on the projects and on their results for the company. Moreover, on the other side, the portfolio management functions are usually performs by senior management, by its direct advisors or even by its functional managers. Such functions are often far from projects, from their challenges and day-to-day operations, what is necessary for them to succeed. Realizing them requires that the PMO have a day-to-day distance from the projects.

On the other hand, program management functions require, in the same time, proximity of projects and a greater access to the demands of business strategy, i.e., a connection function, which may be better performed by PMOs, rather than the specific demands of projects or portfolio. Thus, besides finding a scope of action for the PMO, avoiding overlapping of functions of the project managers, or of the functional managers and senior management advisories, which would allow them to contribute effectively to the results for the company.

The results of this research cannot be generalized either by its sample or by the fact that some functions, which would imply in aspects of Program Management, did not appear as effective in relation to the performance indicators used. Functions such as Implement and manage the lessons learned database, Implement and manage the risk database, Provide coaching for project managers, Provide proactive ways for organizational learning between projects, Coordination between projects, Manage files of project documentation, Manage programs should have presented some correlation with the cost indicator, but it was not observed here.

Future research can be formatted in order to deeply explore how the function of Benefits Management can influence cost performance. It means to determine mechanisms by which this function may result in positive outcomes in order to extract best practices in its execution, including the relation between PMO and program manager's activities. Moreover, a more expressive sample, eventually an international one, can be used to explore relations between the functions of PMOs for NPD projects and performance indicators.

\section{References}

Ali, A., Krapfel, J. R., \& LaBahn, D. (1995). Product Innovativeness and Entry Strategy: Impact on Cycle Time and Break-Even Time. Journal of Product Innovation Management, 12(1), 54-69. https://doi.org/10.1016/0737-6782(94)00027-D

Aubry, M., Hobbs, B., Müller, R., \& Blomquist, T. (2010). Project management offices in transition. International Journal of Project Management, 28, 766-778. https://doi.org/10.1016/j.ijproman.2010.05.006

Barbalho, S. C. M., \& Toledo, J. C. (2014). Caracterização do perfil e dos principais direcionadores de transições em escritórios de projetos: Estudo de caso longitudinal em uma empresa de alta tecnologia. Gestão \& Produção, 21(3), 600-620. https://doi.org/10.1590/0104-530X365

Barbalho, S. C. M., Amaral, D. C., Kernbichler, T. S., Richter, E. H., \& Torres, L. (2009). Rompendo obstáculos para a implantação de escritório de projetos em empresa de base tecnológica. Gestão \& Produção, 16, 435-449. https://doi.org/10.1590/S0104-530X2009000300010

Barbalho, S. C. M., Carvalho, V. G., Silva, G. L., \& Toledo, J. C. (2016). Analyzing the impact of the functions of Project Management Offices on triple constraints performance of new product projects. Product: Management \& Development, 14(2), 85-94. https://doi.org/10.4322/pmd.2016.009

Barbalho, S. C. M., Silva, G. L., \& Toledo, J. C. (2017). The impact analysis of functions of Project Management Office on perfor-mance of triple constraint of new-product development projects. Dirección y Organización, 61, 19-31.

Barbalho, S. C. M., Toledo, J. C., Rojic, J., \& Sillos, M. A. (2014). Funções dos escritórios de projetos no desenvolvimento de produtos: pesquisa-ação em empresa de alta tecnologia. Production, 24(2), 322-336. https://doi.org/10.1590/S0103-65132013005000055

Benjamini, Y., \& Hochberg, Y. (1995). Controlling the False Discovery Rate: A Practical and Powerful Approach to Multiple Testing. Journal of the Royal Statistical Society, 57, 289-300.

Breese, R., Jenner, S., Serra, C. E. M., \& Thorp, J. (2015). Benefits management: Lost or found in translation. International Journal of Project Management, 33(7), 1438-1451. https://doi.org/10.1016/j.ijproman.2015.06.004

Bussab, W. O., \& Morettin, P. A. (2003). Estatística Básica. Editor Saraiva (5th edition), São Paulo.

Chiesa, V., \& Frattini, F. (2007). Exploring the differences in performance measurement between research and development: evidence from a multiple case study. $R \& D$ Management, 37(4), 283-301. https://doi.org/10.1111/j.1467-9310.2007.00476.x

Clark, K. B., \& Fujimoto, T. (1991). Product development performance: strategy, organization and management in the 
world auto industry. Harvard Business School Press. Boston, Massachusetts.

Conforto, E. C., Salum, F., Amaral, D. C., Da Silva, S. L., \& Almeida, L. F. M. (2014). Can Agile Project Management Be Adopted by Industries Other than Software Development? Project Management Journal, 45, 21-34. https://doi.org/10.1002/pmj.21410

Cooper, R., \& Kleinschmidt, E. J. (1995). Benchmarking the firm's critical success factors in new product development. Journal of Product Innovation Management, 12, 374-391. https://doi.org/10.1016/0737-6782(95)00059-3

Crawford, L. (2002). The strategic project office: A guide to improving organizational performance. Marcel Dekker Inc, New York, NY.

Da Silva, C. E. S., Mello, C. H. P., Siqueira, N. F. G., Godoy, H. A., \& Salgado, E. G. (2010). Aplicação do gerenciamento de riscos no processo de desenvolvimento de produtos em empresas de autopeças. Produção, 20(2), 200-213. https://doi.org/10.1590/S0103-65132010005000023

Da Silva, S. L., Toledo, J. C., Mendes, G. H. S., \& Jugend, D. (2007). Critical success factors on product development management in Brazilian technological based companies. 14th ISPE International Conference on Concurrent Engineering-Research and Application. São Paulo, Brazil, 739-747. https://doi.org/10.1007/978-1-84628-976-7_81

Dai, C. X., \& Wells, W. G. (2004). An exploration of project management office features and their relationship to project performance. International Journal of Project Management, 22, 523-532. https://doi.org/10.1016/j.ijproman.2004.04.001

Garcia, J. G. (1995). Análise de la información mercadológica através de la estatística multivariante. Ciudad de Mexico: Alambra Mexicana, p. 235.

Garel, G. (2013). A history of project management models: From pre-models to the standard models. International Journal of Project Management, 31, 663-669. https://doi.org/10.1016/j.ijproman.2012.12.011

Griffin, A., \& Page, A. L. (1996). PDMA success measurement project: recommended measures for product development success and failure. Journal of Product Innovation Management, 13, 478-494. https://doi.org/10.1016/S0737-6782(96)00052-5

Heiberger, R. M., \& Holland, B. (2004). Statistical Analysis and Data Display. Springer-Verlag, 1st. edition, New York. https://doi.org/10.1007/978-1-4757-4284-8

Hobbs, B., \& Aubry, M. (2007). A multi-phase research program investigating project management offices (PMOs): the results of phase 1. Project Management Journal, 38(1), 74-86.

Hochberg, Y. (1988). A Sharper Bonferroni Procedure for Multiple Significance Testing. Biometrika, 75, $800-803$. https://doi.org/10.1093/biomet/75.4.800

Hommel, G. (1988). A Comparison of Two Modified Bonferroni Procedures. Biometrika, 75, $383-386$. https://doi.org/10.1093/biomet/75.2.383

Jordão, R. V. D., Pelegrini, F. G., Jordão, A. C. T., \& Jeunon, E. E. (2015). Fatores críticos na gestão de projetos: um estudo de caso numa grande empresa latino-americana de classe mundial. Gestão \& Produção, 22(2), $280-294$. https://doi.org/10.1590/0104-530X1091-13

Jucá, J. A. S., Conforto, E. C., \& Amaral, D. C. (2010). Maturidade em gestão de projetos em pequenas empresas desenvolvedoras de software do Pólo de Alta Tecnologia de São Carlos. Gestão \& Produção, 17(1) $181-194$. https://doi.org/10.1590/S0104-530X2010000100014

Jugend, D., \& Silva, S. L. (2010). Práticas de gestão que influenciam o sucesso de novos produtos em empresas de base tecnológica. Produção, 20(3), 335-346. https://doi.org/10.1590/S0103-65132010005000041

Jugend, D., Barbalho, S. C. M., \& Silva, S. L. (2015). Contribuições do escritório de projetos à gestão do portfólio de produtos. Production, 26, 190-202. https://doi.org/10.1590/0103-6513.134313

Julian, J. (2008). How project management office leaders facilitate cross-project learning and continuous improvement. Project Management Journal, 39(3), 43-58. https://doi.org/10.1002/pmj.20071

Kahn, K., Barczak, G., \& Moss, R. (2006). Perspective: establishing an NPD best practices framework. Journal of Product Innovation Management, 23(2), 106-116. https://doi.org/10.1111/j.1540-5885.2006.00186.x

Marioka, S., \& Carvalho, M. M. (2014). Análise de fatores críticos de sucesso de projetos: um estudo de caso no setor varejista. Production, 24(1), 132-143. https://doi.org/10.1590/S0103-65132013005000015

Mendes, G. H. S., \& Toledo, J. C. (2012). Explorando práticas do desenvolvimento de produtos em pequenas e médias 
empresas do setor de equipamentos médico-hospitalares. Gestão \& Produção, 19(1), 103-117. https://doi.org/10.1590/S0104-530X2012000100008

Paladino, A. (2007). Investigating the drivers of innovation and new product success: a comparison of strategic orientations. Journal of Product Innovation Mangament, 24(6), 534-553. https://doi.org/10.1111/j.1540-5885.2007.00270.x

Patah, L. A., \& Carvalho, M. M. (2016). Sucesso a partir de investimento em metodologias de gestão de projetos. Production, 26(1), 129-144. https://doi.org/10.1590/0103-6513.048312

Pellegrinelli, S. (2011). What's in a name: Project or programme? International Journal of Project Management, 29, 232-240. https://doi.org/10.1016/j.ijproman.2010.02.009

Pellegrinelli, S., \& Garagna, L. (2009). Towards a conceptualization of PMOs as agents and subjects of change and renewal. International Journal of Project Management, 27(7), 649-656. https://doi.org/10.1016/j.ijproman.2008.12.001

Project Management Institute [PMI]. (2013). The guide to project management body of knowledge: PMBOK. $5^{\text {th }}$ Edition. Pennsylvania: Project Management Institute.

Rabechini, J. R., Carvalho, M. M., Rodrigues, I., \& Sbragia, R. (2011). A organização da atividade de gerenciamento de projetos: os nexos com competências e estrutura. Gestão \& Produção, 18(2), 409-424. https://doi.org/10.1590/S0104-530X2011000200014

Rijke, J., Herk, S., Zevenbergen, C., Ashley, R., Hertogh, M., \& Heuvelhof, E. (2014). Adaptative programme management through a balanced performance/strategy oriented focus. International Journal of Project Management, 32(7), 1197-1209. https://doi.org/10.1016/j.ijproman.2014.01.003

Roberts, E. B., \& Belotti, P. R. (2002). Managerial determinants of industrial R\&D performance: an analysis of the global chemicals/materials industry. Technological Forecasting \& Social Change, 69(2), 129-152. https://doi.org/10.1016/S0040-1625(01)00151-2

Simes, R. J. (1986). An Improved Bonferroni Procedure for Multiple Tests of Significance. Biometrika, 73, 751-754. https://doi.org/10.1093/biomet/73.3.751

Spalek, S. (2013). Improving Industrial Engineering Performance through a Successful Project Management Office. Inzinerine Ekonomika - Engineering Economics, 24(2), 88-98. https://doi.org/10.5755/j01.ee.24.2.3087

Spelta, A. G., \& Albertin, A. L. (2012). Project Management Offices in the IT Area: A Context-Discriminant Model for their Establishment. Information Systems Management, 29, 40-54. https://doi.org/10.1080/10580530.2012.634296

The Cabinet Office [TCO]. (2011). Managing Successful Programmes. $4^{\text {th }}$ Edition. The Stationery Office, London.

Thiry, M. (2010). Program Management. Gower Publishing Limited. Farnham, UK.

Toledo. J. C., Da Silva, S. L., Alliprandini, D., \& Ferrari, F. M. (2008). Práticas de gestão no desenvolvimento de $\begin{array}{llllll}\text { produtos em } \mathrm{em} & \text { empas }\end{array}$ https://doi.org/10.1590/S0103-65132008000200015

Toledo. J. C., Da Silva, S. L., De Paula, S. M., \& Jugend, D. (2007). Factors influencing new products success in small Brazilian medical and hospital equipment firms. $14^{\text {th }}$ ISPE International Conference on Concurrent Engineering-Research and Application, 657-664. https://doi.org/10.1007/978-1-84628-976-7_72

Ulrich, K. T., \& Eppinger, S. D. (2008). Product design and development. McGraw-Hill Inc. New York, United States.

Unger, B. N., Gemünden, H. G., \& Aubry, M. (2012). The three roles of a project portfolio management office: Their impact on portfolio management execution and success. International Journal of Project Management, 30, 608620. https://doi.org/10.1016/j.ijproman.2012.01.015

Wheelwright, S. C., \& Clark, K. B. (1992). Revolutionizing Product Development: Quantum Leaps in Speed, Efficiency and Quality. New York: Free Press.

\section{Copyrights}

Copyright for this article is retained by the author(s), with first publication rights granted to the journal.

This is an open-access article distributed under the terms and conditions of the Creative Commons Attribution license which permits unrestricted use, distribution, and reproduction in any medium, provided the original work is properly cited. 